\title{
PARASITES IN STOOL SAMPLES IN THE ENVIRONMENT OF ILHA DA MARAMBAIA, RIO DE JANEIRO, BRAZIL: AN APPROACH IN PUBLIC HEALTH
}

Beatriz CORONATO(1), Otilio Machado Pereira BASTOS(1), Rosemere DUARTE(2), Antonio Nascimento DUARTE(2), Valmir LAURENTINO-SILVA(2), Marcos Barbosa de SOUZA(2) \& Claudia Maria Antunes UCHÔA(1)

\begin{abstract}
SUMMARY
This research aimed to describe the frequency of parasites in stool samples in the environment of Ilha da Marambaia, Rio de Janeiro, Brazil. One hundred and five stool samples were collected and processed by the coproparasitological techniques ethyl acetate sedimentation and centrifuge-flotation using saturated sugar solution. Parasites were detected in $81.9 \%$ of the samples, hookworm being the most prevalent, followed by Trichuris vulpis. Ascaris sp. eggs were also found. A high level of evolutive forms of parasites with public health risk was found in stool samples of the environment studied. We propose that health education programs, allied to an improvement of human and animal health care, must be employed to reduce the environmental contamination.
\end{abstract}

KEYWORDS: Zoonotic parasites; Hookworms; Dogs; Soil.

\section{INTRODUCTION}

Companion animals play a pivotal role in the transmission of some parasites to humans, acting as definitive or reservoir hosts for helminths and protozoa species. The free access of dogs to household surroundings, as well as to public areas, is an important factor of environmental contamination by feces containing intestinal parasites ${ }^{2}$. Additionally, some of these agents have zoonotic potential and remain viable in water and soil, until they infect a new host ${ }^{1}$.

Several studies performed worldwide, especially in tropical areas, have underscored the importance of dogs in the transmission of zoonotic parasites such as Ancylostoma sp. (hookworms), Toxocara canis, Cryptosporidium sp. and Giardia sp., as well as the high impact of these infections in public health ${ }^{4,9,12,13}$. Despite the large number of reports on zoonotic parasites in public parks, beaches and recreational areas, there is a lack of studies about these agents in restricted geographical areas, such as islands. Since the access to these areas is limited, their epidemiological conditions may be rather singular, thus demanding special attention.

The aim of this study was to investigate the frequency of parasites relevant to public health in stool samples collected in the environment of Ilha da Marambaia, Rio de Janeiro, Brazil.

\section{MATERIAL AND METHODS}

This study was performed on Ilha da Marambaia $\left(23^{\circ} 04^{\prime} \mathrm{S}\right.$, $43^{\circ} 53^{\prime} \mathrm{W}$ ), district of Mangaratiba, located in the Southern region of the state of Rio de Janeiro, in Brazil. Measuring $81 \mathrm{Km}^{2}$ this area is like an island, but is connected to the continent by a barrier beach ("restinga" vegetation). Moreover, it is under the administration of the Brazilian Navy and does not provide pedestrians access to the continent. The access to the locality is only possible by boat and with the authorization of the military forces, with restrictions applying to both human and animals. The total population was estimated at 350 inhabitants in 2010, living in 95 households spread over six beaches. The region's inhabitants depend on subsistence economy, mainly fishery. It is also characterized by poor housing, precarious basic sanitation, as well as an inefficient garbage collection. Around 120 dogs were identified in inhabited areas. They are mostly unrestrained, with access to all areas surrounding households and passageways of inhabitants. In addition to the presence of animal feces in this area, there are accounts of people defecating on the soil of the region.

From September 2010 to April 2011, in six different visits, all fresh stools resembling dog feces were collected, chilled and transported to the laboratory. A total of 105 samples were collected from the environment. The sampling was equally made at sand stretches leading to the six beaches, in addition to the soil around households.

Stool samples were processed by ethyl acetate sedimentation ${ }^{16}$ and centrifuge-flotation using saturated sugar solution ${ }^{7}$ techniques. Each sample was microscopically examined with 100x and 400x microscope magnifications and the parasitic agents were identified based on 


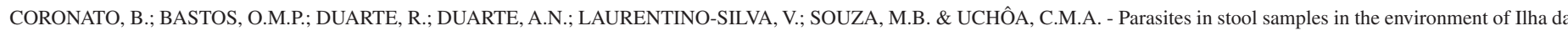
Marambaia, Rio de Janeiro, Brazil: an approach in public health. Rev. Inst. Med. Trop. Sao Paulo, 54(2): 65-7, 2012.

morphological characteristics and measurement of structures, using ocular micrometer (Olympus SWH, Center Valley, PA, USA).

\section{RESULTS}

Of the 105 samples, $81.9 \%$ (86) presented at least one parasitic species. Hookworms were the most frequent parasites, found in $91.9 \%$ of the positive samples. By the time of the microscopic examination, most hookworm eggs contained larvae. Multiple infections occurred in $41.9 \%$ of the positive samples and the most frequent association was detected between hookworms and Trichuris vulpis (32.6\%). It is also worth noting that seven samples were positive for Ascaris sp. eggs. Results are shown in Table 1.

Table 1

Frequency of parasites in 105 stool samples collected in the environment of Ilha da Marambaia, Rio de Janeiro, Brazil, detected by ethyl acetate sedimentation and centrifuge-flotation using saturated sugar solution

\begin{tabular}{lcc}
\hline Parasites & Positive samples & Prevalence $(\%)$ \\
\hline Hookworm & 79 & 91.9 \\
Trichuris vulpis & 31 & 36.0 \\
Ascaris sp. & 7 & 8.1 \\
Nematode larvae & 4 & 4.6 \\
Toxocara canis & 3 & 3.5 \\
Dipylidium caninum & 1 & 1.2 \\
\hline
\end{tabular}

In these seven samples, two contained only Ascaris sp. eggs, three had hookworm and Ascaris sp. eggs, one had hookworm, Ascaris sp. and Trichuris vulpis eggs, and the last one had hookworm, Ascaris sp. and Dipylidium caninum eggs.

\section{DISCUSSION AND CONCLUSIONS}

This study has found a high level of parasitism in the stool samples examined, mostly presenting parasitic forms that require further development in the soil, with favorable conditions, prior to infecting a new host.

Hookworms were the most frequent parasites observed and, to this extent, they were considered the most important infective agent in the environment studied. Ancylostoma sp. is considered the main intestinal parasite of dogs in Brazil, and A. caninum is regarded as the most pathogenic species for dogs. This parasite presents larvae and adults of different species involved in human infections ${ }^{8}$. The high prevalence of Ancylostoma sp. stands as a major concern for public health, not only due to cutaneous larva migrans, but also owing to human eosinophilic enteritis, which may occur when the larvae of this parasite are swallowed by humans ${ }^{11}$.

The dimensions of Trichuris sp. eggs (70.6 - $87.5 \mu \mathrm{m}$ in length by $31.9-41.2 \mu \mathrm{m}$ in diameter), found in 31 samples in this study, were compatible with $T$. vulpis, suggesting that these positive samples were from dogs. The frequency of this agent was higher than those reported in recent studies performed in public areas in Brazil ${ }^{8,10}$.
Other evolutive forms of the parasites found in this research, such as hookworms and Ascaris eggs, were classified in the genus level, since several eggs from different parasite species have the same morphometry, but different host species ${ }^{15}$.

The presence of Ascaridida eggs in fecal samples that contained only Ascaridida eggs (two samples) suggests that these feces could be from humans or swine, infected with Ascaris lumbricoides or A. suum, respectively. Although eggs of Baylisascaris genus have been described in both canine and human infections and are indistinguishable from Ascaris sp., this parasite has never been reported in Brazil ${ }^{6}$. Insofar as the inhabitants of the Ilha da Marambaia have the habit to defecate on the soil, this study suggests that a possible source of environmental contamination for the said parasite was probably humans infected with $A$. lumbricoides. Furthermore, MANDARINO-PEREIRA et al. $(2010)^{10}$ described a similar scenario in the public areas of the state of Rio de Janeiro.

In this study, two samples which had Ascaris sp. also revealed parasites commonly found in dogs, such as T. vulpis and D. caninum. Furthermore, a recent study performed in another tropical area reported the presence of A. lumbricoides, by polymerase chain reaction, in stool samples from dogs; this suggests the ingestion of human feces by these dogs ${ }^{14}$. Nevertheless, T. vulpis and D. caninum had also been described rarely in human infections ${ }^{5,9}$. Thus, based on the results presented, determining the source of environmental fecal contamination is not possible, since microscopic identification of eggs was the only survey method employed.

The behavior of dogs which roam freely in this region poses a risk to public health and promotes cyclical infections in the canine population. Moreover, the lack of veterinary assistance in the region studied may contribute to the high level of infection, mainly determined by the absence of diagnosis and treatment of parasitism in animal population.

It is also important to highlight that individuals walking barefoot was a typical picture observed in the region. In addition to this, there were accounts of the people's habit of defecating on the soil, which could represent an important factor in macro- and micro-epidemiology of parasitic zoonosis, as well as in human soil transmitted helminth infections ${ }^{3}$.

In spite of this, the scenario observed in this study is in keeping with the significant relationship between the high prevalence of parasites and the low social and economic status, including the poor sanitary conditions and lack of information about prevention of parasitosis ${ }^{3,4}$.

These results point to a high level of environmental contamination with stool samples containing evolutive forms of parasites, which suggests the possibility of transmission of parasites both to human and animal populations. Health education programs, allied to an improvement in attention of human and animal health care, must be furthered to reduce the environmental contamination on Ilha da Marambaia and, presumably, in other tropical areas.

\section{RESUMO}

Parasitos em amostras fecais de ambiente da Ilha da Marambaia, Rio de Janeiro, Brasil: uma abordagem em saúde pública

O objetivo deste estudo foi descrever a frequência de parasitos em 
CORONATO, B.; BASTOS, O.M.P.; DUARTE, R.; DUARTE, A.N.; LAURENTINO-SILVA, V.; SOUZA, M.B. \& UCHÔA, C.M.A. - Parasites in stool samples in the environment of Ilha da Marambaia, Rio de Janeiro, Brazil: an approach in public health. Rev. Inst. Med. Trop. Sao Paulo, 54(2): 65-7, 2012.

amostras fecais coletadas no ambiente da Ilha da Marambaia, Rio de Janeiro, Brasil. Cento e cinco amostras foram coletadas e processadas pelas técnicas coproparasitológicas de sedimentação em acetato de etila e centrifugo-flutuação em solução saturada de sacarose. Foi observada positividade em $81.9 \%$ das amostras, sendo ancilostomídeo o parasito mais frequente, seguido de Trichuris vulpis. Ovos de Ascaris sp. também foram detectados. Observou-se elevada frequência de parasitos com importância em saúde pública nas fezes recolhidas no ambiente. Programas de educação em saúde, aliados a atenção dos serviços das saúdes humana e animal, devem ser empregados para redução dos níveis de contaminação ambiental.

\section{ACKNOWLEDGEMENTS}

The authors would like to thank the Brazilian Navy.

\section{CONFLICT OF INTEREST}

The authors declare that there is no conflict of interest.

\section{REFERENCES}

1. Acunã A, Calegari L, Curto S, Lindner C, Rosa R, Salvatella R, et al. Helminthiasis intestinales. Manejo de las geohelminthiasis. Montevideo: Organización Panamericana de la Salud; 2003.

2. Dado D, Izquierdo F, Vera O, Montoya A, Mateo M, Fenoy S, et al. Detection of zoonotic intestinal parasites in public parks of Spain. Potential epidemiological role of Microsporidia. Zoonoses Public Health. 2012;59:23-8. doi: 10.1111/j.18632378.2011.01411.x.

3. De Silva NR, Brooker S, Hotez PJ, Montresor A, Engels D, Savioli L. Soil-transmitted helminth infections: updating the global picture. Trends Parasitol. 2003;19:547-51.

4. Devera R, Blanco Y, Hernández H, Simoes D. Toxocara spp. and other helminths in squares and parks of Ciudad Bolívar, Bolivar State (Venezuela). Enferm Infecc Microbiol Clin. 2008;26:23-6.

5. Dunn JJ, Columbus ST, Aldeen WE, Davis M, Carroll KC. Trichuris vulpis recovered from a patient with chronic diarrhea and five dogs. J Clin Microbiol. 2002;40:2703-4.
6. Gavin PJ, Kazacos KR, Shulman ST. Baylisascariasis. Clin Microbiol Rev. 2005; $18: 703-18$

7. Huber F, Bomfim TC, Gomes RS. Comparação da eficiência da técnica de sedimentação pelo formaldeído-éter e da técnica de centrífugo-flutuação modificada na detecção de cistos de Giardia sp. e oocistos de Cryptosporidium sp. em amostras fecais de bezerros. Rev Bras Parasitol Vet. 2003;12:135-7.

8. Katagiri S, Oliveira-Sequeira TC. Prevalence of dog intestinal parasites and risk perception of zoonotic infection by dog owners in São Paulo State, Brazil. Zoonoses Public Health. 2008;55:406-13.

9. Klimpel S, Heukelbach J, Pothmann D, Rückert S. Gastrointestinal and ectoparasites from urban stray dogs in Fortaleza (Brazil): high infection risk for humans? Parasitol Res. 2010;107:713-9.

10. Mandarino-Pereira A, de Souza FS, Lopes CW, Pereira MJ. Prevalence of parasites in soil and dog feces according to diagnostic tests. Vet Parasitol. 2010;170:176-81.

11. Prociv P, Croese J. Human enteric infection with Ancylostoma caninum: hookworms reappraised in the light of a "new" zoonosis. Acta Trop. 1996;62:23-44.

12. Sevá AP, Funada MR, Souza SO, Nava A, Richtzenhain LJ, Soares RM. Occurrence and molecular characterization of Cryptosporidium spp. isolated from domestic animals in a rural area surrounding Atlantic dry forest fragments in Teodoro Sampaio municipality, State of São Paulo, Brazil. Rev Bras Parasitol Vet. 2010;19:249-53.

13. Soriano SV, Pierangeli NB, Roccia I, Bergagna HF, Lazzarini LE, Celescinco A, et al. A wide diversity of zoonotic intestinal parasites infects urban and rural dogs in Neuquén, Patagonia, Argentina. Vet Parasitol. 2010;167:81-5.

14. Traub RJ, Robertson ID, Irwin P, Mencke N, Thompson RC. The role of dogs in transmission of gastrointestinal parasites in a remote tea-growing community in northeastern India. Am J Trop Med Hyg. 2002;67:539-45.

15. Vicente JJ, Rodrigues HO, Gomes DC, Pinto RM. Nematóides do Brasil. Parte V: nematóides de mamíferos. Rev Bras Zool. 1997;14(Suppl 1):1-452.

16. Young KH, Bullock SL, Melvin DM, Spruill CL. Ethyl acetate as a substitute for diethyl ether the formalin-ether sedimentation technique. J Clin Microbiol. 1979;10:852-3.

Received: 29 September 2011

Accepted: 10 January 2012 


\section{LIBRARY OF THE SÃO PAULO INSTITUTE OF TROPICAL MEDICINE}

Website: www.imt.usp.br/portal

Address: Biblioteca do Instituto de Medicina Tropical de São Paulo da Universidade de São Paulo Av. Dr. Enéas de Carvalho Aguiar, 470. Prédio 1 - Andar térreo.

05403-000 São Paulo, SP, Brazil.

Telephone: 5511 3061-7003 - Fax: 5511 3062-2174

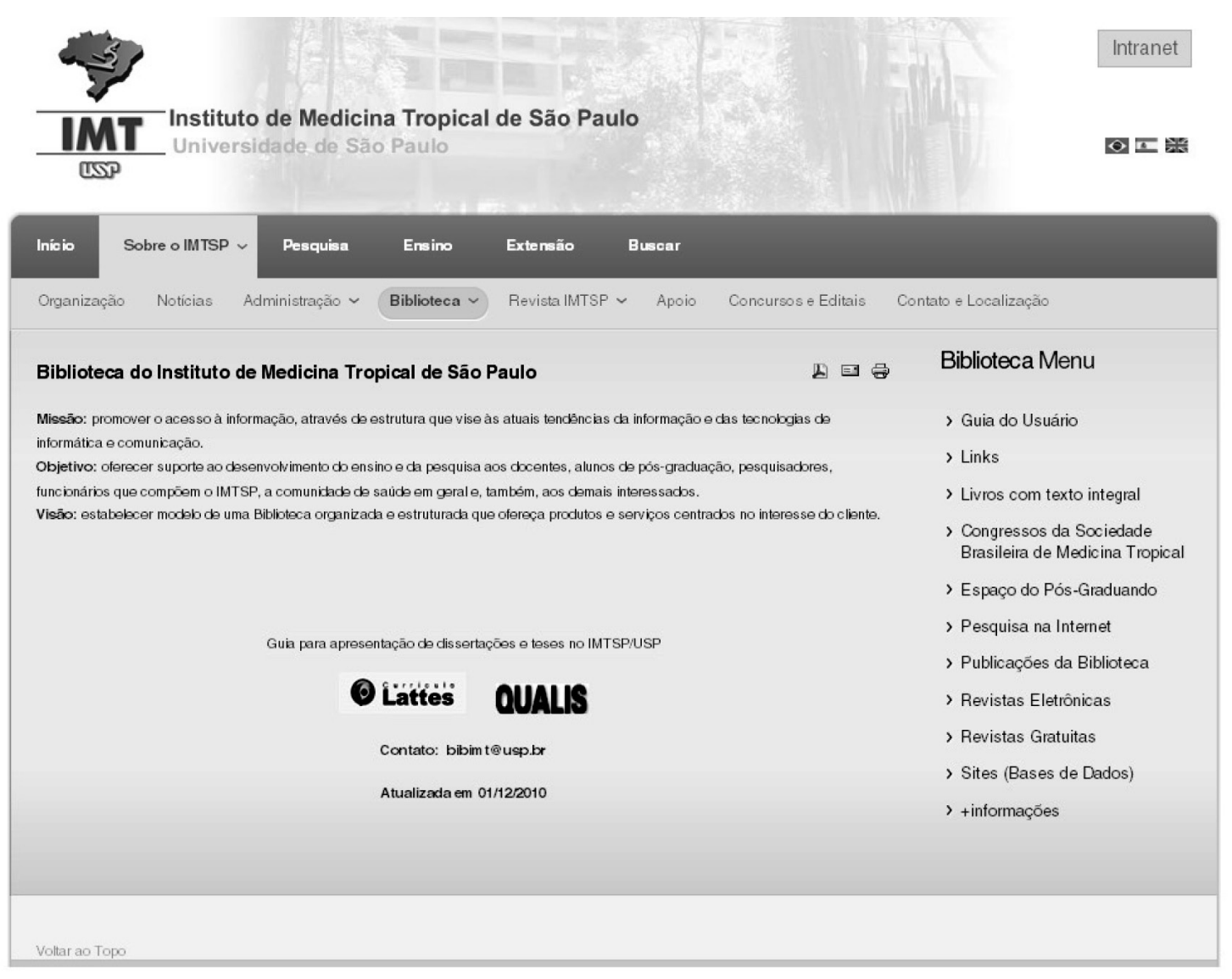

The Library of the São Paulo Institute of Tropical Medicine (IMTSP Library) was created on January 15,1959 in order to serve all those who are interested in tropical diseases. To reach this objective, we select and acquire by donation and / or exchange appropriate material to be used by researchers and we maintain interchange between Institutions thorough the Journal of the São Paulo Institute of Tropical Medicine, since the Library has no funds to build its own patrimony.

The IMTSP Library has a patrimony consisting of books, theses, annals of congresses, journals, and reference works.

The collection fo journals existing in the Library can be verified through the USP - Bibliographic Database - OPAC - DEDALUS http://dedalus.usp.br:4500/ALEPH/eng/USP/USP/DEDALUS/start of the USP network. 